\title{
Ergonomic Evaluation of Farm Women during Using Okra Cutter
}

\author{
Neelu Vishwakarma ${ }^{1 *}$, D.P.Sharma ${ }^{2}$, Alpana Sharma ${ }^{3}$ and Pramod Sharma ${ }^{1}$ \\ ${ }^{1} J N K V V-K r i s h i$ Vigyan Kendra, Jabalpur (MP), India \\ ${ }^{2} J N K V V$-DES, Jabalpur (MP), India \\ ${ }^{3} J N K V V$-Krishi Vigyan Kendra, Shahdol (MP), India \\ *Corresponding author
}

\section{A B S T R A C T}

Agriculture is an important unorganized sector where majority of the women labour force is engaged. Women as agricultural labourers, participate in several activities such as seeding, transplanting, weeding, fertilizer application, plant protection,

\section{Keywords}

Traditional tool, Physiological cost, Heart rate, Average heart rate,

Discomfort

\section{Article Info}

Accepted:

10 April 2020

Available Online:

10 May 2020 thinning, harvesting, processing, selling, harvesting, winnowing, storing, looking after animals, kitchen gardening etc. The farm women adopt long static postures for some of the farm activities, which increase the static muscular effort resulting in high physiological cost and low productivity. The plucking efficiency, energy expenditure, carrying capacity, ease, comfort, safety, loading and unloading etc. were documented for comparison.Present Study was carried out in three districts named Jabalpur, Mandla and Katni. Under these districts eleven okra grower villages were selected. Front Line Demonstration was conducted under Krishi Vigyan Kendra, Jabalpur, Mandla and Katni during Year 2016, 2017 and 2018-19. A total of 60 farm women were selected for the study. The study mainly dealt with ergonomic evaluation of harvesting of okra by okra cutter. It is very useful to saves time and energy. Physiological responses and physiological cost of work is reduced significantly. The result of the study reveals increased efficiency and reduce HR work, ÄHR whereas output is concerned it was $6.8 \mathrm{~kg} / \mathrm{h}$ by hand harvesting which increased to $9.84 \mathrm{~kg} / \mathrm{h}$ by okra cutter increasing the output by $44 \%$.

\section{Introduction}

Women in rural India play a major role in shaping the economy of the country. Agriculture is an important sector where majority of the women labour force is engaged. The rural women play significant role in agriculture and agro processing activities. The daily work schedule of rural women is very demanding and arduous.
Women as agricultural labourers, participate in several activities such as seeding, transplanting, weeding, fertilizer application, plant protection, thinning, harvesting, processing, selling, harvesting, winnowing, storing, looking after animals, kitchen gardening etc.

Majority of the farm women doing hand harvesting without gloves and mostly affected 
from pesticides exposure. Though, this method efficiency of agriculture from labour increases and drudgery to reduced. Farm women have anatomical and physiological differences that may place them at risk of farm injuries (Engber, 1993). The farm women adopt long static postures, which increase the static muscular effort resulting in high physiological cost and less productivity. There is a need to design women friendly tools and equipment as women can comfortably operate these tools and equipment. Use of Improved tools will reduce musculoskeletal disorders and increase the efficiency and there by productivity of the worker. Karam et al. (2009) suggested that the best way to prevent an injury is to eliminate the hazards. Oberoi et al. (2006) conducted a study to assess the muscular stress of rural women while performing different household, allied and farm activities with the use of traditional as well as improved tools. This ergonomic study on okra harvesting by traditional and improved method is conducted to find discomfort level, energy expenditure, efficiency, comfort, safety, loading and unloading and several factors involved during okra plucking operation.

Table 1 Depicts Area, Production, Number of growers and number of laborers in various villages of Majholi block of Jabalpur District. Table depicts that in this block, total area of Okra production was 182.8 ha and 742 Qt/ year was the production.

Okra production in Mandla block of Mandla district with its area, number of growers and number of laborers was presented in Table 2 . It shows that total area of production is 43.5 ha with 147 Qt/year production.

Table 3 shows the okra production, its area, number of growers and number of laborers in in Mandla Block of Mandla district. Total area in this block was 27 ha with annual production of $75 \mathrm{Qt}$.

\section{Materials and Methods}

To demonstrate the safe method for protected hazards and injury during the okra harvesting, the work was conducted among 60 farmwomen at three district named Jabalpur, Mandla and Katni of Madhya Pradesh in their adopted villages. Heart rate is measuring an ergonomic measure to evaluate the physiological or functional demands of work on the individual workers (Hasalkar et al 2004). Thus the heart rate response method was used that measures the change in heart rate and uses it to calculate the energy expenditure during okra plucking activity. The present study was undertaken to assess the drudgery and efficiency enhancement during okra harvesting by the use of cutter.

The time was recorded using stop watch. Heart rate monitor was used to measure the heart rate. All other parameters were calculated from the heart rate measurement. Average heart rate was calculated during rest and work. The energy expenditure per minute was calculated from the heart rate with the help of formula given by Varghese et al., (1994).

Energy expenditure $(\mathrm{kj} / \mathrm{min})=0.159 \mathrm{x}$ Average heart rate (beats/min) -8.72

$\Delta \mathrm{HR}$ (beats $/ \mathrm{min})=$ Average working heart rate - Average heart rate during rest

Output $(\mathrm{kg} / \mathrm{h})=$ Weight of picked Okra $\mathrm{x}$ duration/average time

\section{Results and Discussion}

The ergonomic evaluation of harvesting of okra activity was done. For this purpose 24 respondents of the age group of 25 to 55 years were randomly selected. The mean age count, average height and weight of respondents were 39.8 years, $154.26 \mathrm{~cm}$ and $52.23 \mathrm{~kg}$ respectively. 
The results revealed that majority of the women $(43.3 \%)$ harvesting of okra in the farm were in between 31-40 years followed by below 30 years $(8.3 \%)$, above 51 years $(11.6 \%)$ and between $41-50$ years (36.3\%). Nearly forty three percent of the farm women had above six years of work experience whereas only 8.3 percent of farm women had below 30 years of age which implies that since the sample comprised of only 11.6 percent of women aged above 51 years, had long years of work experience but there efficiency was low due to less physical fitness
Table 5 revealed that the majority of the respondents had musculoskeletal problems of farm women during the harvesting of Okra. The problems pertaining to illness, injuries and disorders related to musculoskeletal systems in the neck, shoulder, arms and hands are well recognized (Anderson, 1984; Kroemer, 1989; Bhattacharya and Meglothlin, 1996). Data given in Table 6 reveal that 7.9 $\mathrm{kg}$ harvesting of okra by age between 31-40 years of manually (hand harvesting) while output11.2 kg by okra cutter.

Table.1 Farmers Involve to okra production in Majholi Block of Jabalpur district, MP

\begin{tabular}{|l|c|c|c|c|}
\hline Village & Area (ha) & $\begin{array}{c}\text { Production(Qt) } \\
\text { /year }\end{array}$ & $\begin{array}{c}\text { No. of } \\
\text { Growers }\end{array}$ & No. of labours \\
\hline Nanghat & 60 & 280 & 134 & 450 \\
\hline Talad & 50 & 195 & 130 & 580 \\
\hline Mohla Bargi & 14 & 62 & 72 & 290 \\
\hline Darshni & 50 & 180 & 102 & 233 \\
\hline $\begin{array}{l}\text { Khamariya } \\
\text { (Behar) }\end{array}$ & 8.8 & 25 & 24 & 69 \\
\hline Total & $\mathbf{1 8 2 . 8}$ & $\mathbf{7 4 2}$ & $\mathbf{4 6 2}$ & $\mathbf{1 6 2 2}$ \\
\hline
\end{tabular}

Table.2 Farmers involve to okra production in Mandla Block of Mandla district, MP

\begin{tabular}{|l|c|c|c|c|}
\hline Village & Area (ha) & $\begin{array}{c}\text { Production(Qt) } \\
\text { /year }\end{array}$ & $\begin{array}{c}\text { No. of } \\
\text { Growers }\end{array}$ & No. of labours \\
\hline Nadiya & 15 & 52 & 32 & 38 \\
\hline Piparpani & 10 & 27 & 18 & 16 \\
\hline Sakwah & 18.5 & 68 & 22 & 20 \\
\hline Total & $\mathbf{4 3 . 5}$ & $\mathbf{1 4 7}$ & $\mathbf{7 2}$ & $\mathbf{7 4}$ \\
\hline
\end{tabular}

Table.3 Farmers Involve to okra production in Mandla Block of Katni district, MP

\begin{tabular}{|l|c|c|c|c|}
\hline Village & Area (ha) & $\begin{array}{c}\text { Production (Qt) } \\
\text { /year }\end{array}$ & $\begin{array}{c}\text { No. of } \\
\text { Growers }\end{array}$ & No. of labours \\
\hline Teori & 12 & 30 & 26 & 20 \\
\hline Lingri & 5 & 18 & 20 & 8 \\
\hline Lakhapateri & 10 & 27 & 28 & 14 \\
\hline Total & $\mathbf{2 7}$ & $\mathbf{7 5}$ & $\mathbf{7 4}$ & $\mathbf{4 2}$ \\
\hline
\end{tabular}


Table.4 Anthropometric measurements

\begin{tabular}{|l|l|}
\hline Physical characteristic & Mean \pm SD \\
\hline Age $($ years) & $39.8 \pm 8.00$ \\
Height $(\mathbf{c m})$ & $154.26 \pm 5.128$ \\
Weight $(\mathbf{k g})$ & $52.23 \pm 3.95$ \\
\hline
\end{tabular}

Table.5 Distribution of sample by age

\begin{tabular}{|l|c|c|c|}
\hline Age in years farmwomen & $\begin{array}{c}\text { Frequency } \\
(\mathbf{N = 6 0 )}\end{array}$ & $\begin{array}{c}\text { Percentages } \\
(\mathbf{\%})\end{array}$ & Mean \pm S.D \\
\hline Below 30 years & 5 & 8.3 & $27.80 \pm 2.28$ \\
\hline Between 31-40 years & 26 & 43.3 & $34.35 \pm 2.17$ \\
\hline Between 41-50 years & 22 & 36.6 & $44.18 \pm 2.32$ \\
\hline Above 51 years & 7 & 11.6 & $54.86 \pm 1.95$ \\
\hline
\end{tabular}

Table.6 Performance and problems of harvesting of okra

\begin{tabular}{|c|c|c|c|c|}
\hline \multirow{2}{*}{$\begin{array}{l}\text { Subject } \\
\text { Age } \\
\text { Group }\end{array}$} & \multicolumn{2}{|r|}{ Traditional } & \multicolumn{2}{|c|}{ Okra cutter } \\
\hline & $\begin{array}{l}\text { Av. Quantity } \\
\text { harvested } \\
\text { No/hr, kg/hr }\end{array}$ & Remarks from subject & $\begin{array}{l}\text { Av. Quantity } \\
\text { harvested } \\
\text { No/hr, kg/hr }\end{array}$ & Remarks from subject \\
\hline $\begin{array}{l}\text { Below } 30 \\
\text { years }\end{array}$ & $570,7.55$ & $\begin{array}{l}\text { Health hazards and accidents while } \\
\text { performing okra harvesting hand } \\
\text { harvesting }\end{array}$ & $820,10.72$ & $\begin{array}{l}\text { Easy to operate, feeling } \\
\text { presser to thumb and } \\
\text { center. }\end{array}$ \\
\hline $\begin{array}{l}\text { Between } \\
31-40 \\
\text { years }\end{array}$ & $604,7.9$ & $\begin{array}{l}\text { Very difficult activity for farmwomen } \\
\text { due to pricking of thorns and prickles } \\
\text { and skin contact of natural secretion } \\
\text { of plant }\end{array}$ & $847,11.2$ & $\begin{array}{l}\text { Women experienced } \\
\text { moderate relief in } \\
\text { itching experience in } \\
\text { hands and pain in hands }\end{array}$ \\
\hline $\begin{array}{l}\text { Between } \\
\text { 41-50 } \\
\text { years }\end{array}$ & $489,6.85$ & $\begin{array}{l}\text { Wounds, skin irritation and rashes } \\
\text { faced to contact of pesticides }\end{array}$ & $702,9.84$ & $\begin{array}{l}\text { Reduction in Itching of } \\
\text { fingers, roughening of } \\
\text { fingers }\end{array}$ \\
\hline $\begin{array}{l}\text { Above } 51 \\
\text { years }\end{array}$ & $350,4.9$ & $\begin{array}{l}\text { Farm women were having } \\
\text { occupational health problems during } \\
\text { harvesting }\end{array}$ & $542,7.6$ & $\begin{array}{l}\text { Reduced the unhealthy } \\
\text { impact but more time } \\
\text { required to practicing }\end{array}$ \\
\hline
\end{tabular}

Table.7 Ergonomic evaluation during okra harvesting activity

\begin{tabular}{|l|l|l|}
\hline \multirow{2}{*}{ Parameter } & \multicolumn{2}{|c|}{ Mean values \pm SD } \\
\cline { 2 - 3 } & Traditional (by hand harvesting) & Improved (by okra cutter) \\
\hline $\begin{array}{l}\text { Average working heart rate } \\
\text { (beats/min) }\end{array}$ & $84.76 \pm 2.40$ & $93.46 \pm 2.41$ \\
\hline $\begin{array}{l}\text { Average heart rate during } \\
\text { rest (beats/min) }\end{array}$ & $73.05 \pm 2.54$ & $74.16 \pm 2.38$ \\
\hline DHR (beats/min) & $10.79 \pm 2.86$ & $19.3 \pm 3.11$ \\
\hline Output (kg/h) & $6.8 \pm 0.59$ & $9.84 \pm 1.16$ \\
\hline
\end{tabular}


Data given in Table 7 depicts that harvesting of okra $6.8 \mathrm{~kg}$ manually (hand harvesting) while $9.84 \mathrm{~kg}$ by okra cutter. Thus it is very clear that okra cutter saved more than 44 percent of time against the manual/hand harvesting and increased the working efficiency. It was found that the difference between working and resting heart rate $(\Delta H R)$ differ more in okra cutter. Shows change in Heart Rate $(\Delta \mathrm{HR})$ of the farm women during harvesting of okra was 10.79 beats/min by local sieve and 19.3 by Improved Method by okra cutter.

In conclusion, the okra harvesting activity is a very monotonous, repetitive, lengthy and time consuming. Moreover harvesting of okra with thorny stems leads to cuts, injuries, rashes and scratches on the fingers of farm women and tedious activity. This okra cutter proved to be use full for okra harvesting it saves time, labour, energy and economically advantage of the technology. Though the drudgery experience is high in these two okra cutter but work output and safe use is higher than traditional method. Okra cutter is a cutter type of tool of steel/metal with a cutting blade on two sides. This can be hold in index finger like a shear and plucking of okra fruit be easily done. It has tremendous utility for farmwomen working in okra field and also reduces health hazard.

\section{References}

Varghese MA, Saha PN and Atreya N 1994. A rapid appraisal of occupational workload from modified scale of perceived exertion. Ergonomics, 37(3): 485-491.

Chauhan MK 1999. Workload and health problems in some occupational activities. Paper presented in Advanced Training Course in Ergonomics, SNDT Women's University, Mumbai, Maharashtra, India.

Vijaya V. L. and Deepika J. (2019) Performance Evaluation of Ring Cutter in Harvesting Activity Int.J.Curr.Microbiol.App.Sci 8(4): 1838-1843

Vishwakarma N, Sharma A, Kumar A and. Rai H.S,2015, Hanging type double screen grain cleaner- A drudgery reduction boon of tribal farm women, Bioved, 26(1,2): 1-3.

Nalawade S. M., Kad V. P. and Gajakos A V, 2017, Development of Okra-CutterHolder J Krishi Vigyan, 6(1): 54-57.

Sharma A, Vishwakarma N, Singh M, 2019, Ergonomic evaluation during wheat cleaning through hanging type grain cleaner (HTGC), International Journal of Farm Sciences 9(4): 124-126.

\section{How to cite this article:}

Neelu Vishwakarma, D.P. Sharma, Alpana Sharma and Pramod Sharma. 2020. Ergonomic Evaluation of Farm Women during Using Okra Cutter. Int.J.Curr.Microbiol.App.Sci. 9(05): 1380-1384. doi: https://doi.org/10.20546/ijcmas.2020.905.156 